\title{
Áudio-descrição nas Manifestações Artístico Culturais: Uma tradução Intersemiótica
}

\author{
Audiodescripción em las Expresiones Culturales y Artísticas: Una \\ Traducción Intersemiótico
}

\author{
Audio-description in Cultural Artistic Manifestations: An Intersemiotic \\ Translation
}

Bel. João Batista Santana Correia ${ }^{1}$

\begin{abstract}
Resumo
$\mathrm{O}$ presente trabalho buscou identificar e descrever a áudio-descrição - AD - como um recurso de tecnologia assistiva - TA - comunicacional indispensável para a inclusão cultural das pessoas com deficiência visual. Conforme os dados coletados e apresentados, em 2010, pelo IBGE - Instituto Brasileiro de Geografia e Estatística - mais de 45 milhões de pessoas manifestaram possuir algum tipo de deficiência e, destas, 18,60\% informaram ter cegueira ou baixa visão. A AD disponibilizada, "ao vivo" ou gravada, é um direito assegurado pela Constituição Federal de 1988 que, por sua praticidade e efetividade, permite o acesso; a interpretação; a significação, a contextualização e a interação das pessoas com deficiência visual com as produções artísticoculturais. No aspecto teórico, a áudio-descrição se configura como uma tradução ou transmutação intersemiótica caracterizada pela interpretação de um signo não-verbal por meio de um signo verbal, ou seja, a transformação da linguagem imagética, que não é perceptível pela visão, em linguagem verbal que chega por meio da audição à mente da pessoa com deficiência visual adquirindo assim potência suficiente para criar uma imagem mental semelhante ou equivalente àquela que estava presente na produção artístico-cultural. Para a consecução, utilizouse a metodologia qualitativa de cunho bibliográfico fundamentada na teoria de Roman Jakobson (2007) e de Motta; Romeu Filho (2010). Abordou-se a áudio-descrição na perspectiva de sua historicidade; da tradução intersemiótica; do recurso de tecnologia assistiva de acessibilidade comunicacional e da legislação brasileira.
\end{abstract}

Palavras-Chave: Acessibilidade Comunicacional; Áudio-descrição; Pessoa com Deficiência Visual; Tradução Intersemiótica.

\section{Resumen}

El presente trabajo buscó identificar y describir la audio-descripción - AD - como un recurso de tecnología asistiva - TA - comunicacional indispensable para la inclusión cultural de las personas con discapacidad visual. Conforme a los datos recogidos y presentados en 2010 por el IBGE - Instituto Brasileño de Geografía y Estadística - más de 45 millones de personas manifestaron poseer algún tipo de discapacidad y de ellas, el 18,60\% informó tener ceguera o baja visión. La AD disponible, "en vivo" o grabada, es un derecho asegurado por la Constitución Federal de 1988 que, por su practicidad y efectividad, permite el acceso; la interpretación; la significación, la contextualización y la interacción de las personas con discapacidad visual con las producciones artístico-culturales. En el aspecto teórico, la audio-descripción se configura como una traducción o transmutación intersemiótica caracterizada por la interpretación de un signo no verbal por medio de un signo verbal, o sea, la transformación del lenguaje imagético, que no es perceptible por la visión, en lenguaje verbal que llega por medio de la audición a la mente de la persona con discapacidad visual adquiriendo así potencia suficiente para crear una imagen mental semejante o equivalente a la que estaba presente en la producción artístico-cultural. Para la consecución, se utilizó la metodología cualitativa de cuño bibliográfico fundamentada en la teoría de Roman Jakobson (2007) y de Motta; Romeo Filho (2010). Se abordó la audio-descripción en la perspectiva de su historicidad; de la traducción intersemiótica; del recurso de tecnología asistiva de accesibilidad comunicacional y de la legislación brasileña.

1 Bacharel em Relações Públicas; Universidade Federal do Pampa - UNIPAMPA; São Borja; Rio Grande do Sul; Brasil; joaocorreia@unipampa.edu.br. Trabalho apresentado no I Seminário Latino-Americano de Estudos em Cultura - SEMLACult, Foz do Iguaçu/PR, Brasil, 2017. 
Palabras claves: Accesibilidad Comunicacional; Audio-descripción; Persona con discapacidad visual; Traducción Intersemiótica.

\begin{abstract}
The present work sought to identify and describe the audio description - AD - as an assistive technology resource - TA - communicational essential for the cultural inclusion of people with visual impairment. According to the data collected and presented in 2010 by the Brazilian Institute of Geography and Statistics (IBGE), more than 45 million people reported having some kind of disability, and of these, $18.60 \%$ reported having blindness or low vision. The AD made available, "live" or recorded, is a right guaranteed by the Federal Constitution of 1988 that, due to its practicality and effectiveness, allows access; the interpretation; the meaning, contextualization and interaction of people with visual impairment with artistic-cultural productions. In the theoretical aspect, the audio-description is configured as an intersemiotic translation or transmutation characterized by the interpretation of a non-verbal sign by means of a verbal sign, that is, the transformation of the imaginary language, which is not perceptible by sight, in verbal language which arrives by hearing to the mind of the visually impaired person thereby acquiring sufficient power to create a mental image similar or equivalent to that which was present in artistic-cultural production. To achieve this, we used the qualitative methodology based on the theory of Roman Jakobson (2007) and Motta; Romeo Filho (2010). The audiodescription was approached from the perspective of its historicity; of intersemiotic translation; the assistive technology of communicational accessibility and Brazilian legislation.
\end{abstract}

Keywords: Communicational Accessibility; Audio-description; Person with Visual Impairment; Intersemiotic Translation.

\title{
1. Introdução
}

O Censo Demográfico realizado em 2010 pelo Instituto Brasileiro de Geografia e Estatística - IBGE - apontou que mais de 45 milhões de brasileiros manifestaram possuir algum tipo de deficiência e, destes, 18,60\% informaram ter deficiência visual em diferentes graus de comprometimento (OLIVEIRA, 2010). Observando-se somente o aspecto quantitativo, tem-se um contingente humano superior à população de vários países. Extrapolando-se a frieza dos números, desvela-se a realidade de homens e mulheres sequiosos pela oportunidade de exercerem a plena cidadania por intermédio da participação ativa e contributiva nas atividades econômicas, sociais e culturais, independente das diferenças físicas; psíquicas; intelectuais; orgânicas e estruturais apresentadas e que, em última análise, são inerentes ao ser humano.

Não se sabe ao certo quantas produções artístico-culturais, amadoras ou profissionais, foram realizadas no Brasil nos últimos meses, entretanto, imagina-se um grande número. $\mathrm{E}$ destas, quantas são acessíveis às pessoas com deficiência visual? Esta pergunta torna-se emblemática, pois a partir dela penetra-se num mundo de imagens carregadas de gestos, de olhares e de informações, outras que são perceptíveis unicamente através da visão, isto é, destinadas a um grande público, os videntes, mas não a todas as pessoas. Para que se estabeleça o preceito institucional de equidade, de acesso e interação, apresenta-se a áudio- 
descrição - AD - como um recurso de tecnologia - TA - indispensável à inclusão cultural das pessoas com deficiência visual. Conceitua-se AD como

Um dispositivo linguístico desenvolvido para atender as necessidades das pessoas com deficiência visual (PcDVs), quer cegas ou com baixa visão, favorecendo-lhes a acessibilidade a produtos (áudio)visuais e contribuindo, assim, para o seu empoderamento, especialmente como fruidoras de arte (JÚNIOR; FILHO, 2010, p. 23).

A áudio-descrição na prática é um recurso de tecnologia assistiva comunicacional que pode ser "ao vivo" ou gravada. A AD de uma produção artístico-cultural contém o detalhamento, por exemplo, das características pessoais das personagens, do cenário, do figurino e de outros elementos visuais que são imperceptíveis às pessoas cegas ou com baixa visão. No caso da televisão a AD é acionada pela tecla SAP - Second Audio Program - e funciona em separado da faixa de áudio que contém a fala das personagens e a da trilha sonora da produção áudiovisual. No cinema e no teatro a pessoa com deficiência visual utiliza um fone de ouvido para acessar a AD.

$\mathrm{Na}$ teoria, a $\mathrm{AD}$ permite que a linguagem imagética seja traduzida para a linguagem verbal e sonora, e, nessa forma, possa atingir os ouvidos e a mente daquelas pessoas materializando assim, de acordo com Jakobson (2007), a tradução ou transmutação intersemiótica.

Alerta-se que nesse trabalho o vocábulo áudio-descrição foi escrito seguindo a proposta apresentada por Seemann; Lima; Lima (2012) que advogam que essa grafia é a mais apropriada, pois a AD não é somente "uma descrição em áudio, descrição falada ou narrada, mas uma composição a partir da união dos termos áudio e descrição" (SEEMANN; LIMA; LIMA, 2012, p. 4). E sendo assim, elucidam que no

Ponto de vista morfológico, e em consonância com o Acordo Ortográfico da Língua Portuguesa, significa reiterar que grafar áudio-descrição com hífen é entender que este léxico se formou pelo processo de composição, e que o termo encerra um conceito novo e especializado, que não se constitui por um processo de derivação, posto que não é a simples descrição falada, mas que se constitui por um processo de composição, dado que é uma tradução visual dos eventos visuais/imagéticos, destinada, principalmente às pessoas com deficiência visual, pessoas cegas ou com baixa visão. Portanto, grafar áudio-descrição (com hífen) não é meramente um preciosismo linguístico. É, ao contrário, a observância do que determina a Base XV do Decreto $N^{\circ}$. 6.583/2008 e é, principalmente, assumir posição diferenciada sobre a conceituação do termo áudio-descrição, distinguindo-o de descrição em áudio (descrição falada) para conceituá-lo como tradução visual (áudio-descrição daqueles eventos visuais, os quais, por alguma razão, não estejam disponíveis ao indivíduo com deficiência visual e/ou outras), seja porque tais eventos não são/estão deduzidos pelos sons, pela trilha sonora da obra, seja porque não são/estão deduzidos pela 
cognição ou pelo intelecto do espectador/observador (SEEMANN; LIMA; LIMA, 2012, p. 20).

Numa abordagem alicerçada na teria intersemiótica justifica-se, portanto, a adoção da grafia tutelada por estes autores.

Para a contextualização da temática, evoca-se o testemunho de Bazanella (2010), na época com 58 anos e cego desde os cinco, a respeito de algumas experiências, nem todas boas, ao acompanhar a exibição de filmes. Ele recordou a experiência de acompanhar a exibição do filme 2001, Uma Odisseia no Espaço: “[...] só depois do terceiro intervalo sem ouvir uma palavra sequer, tendo apenas um zumbido como garantia de que a TV permanecia ligada, foi que desisti de “ver' tal programação" (BAZANELLA, 2010, p. 209).

Num evento ou produto artístico-cultural, gravado ou "ao vivo", a utilização da tecnologia assistiva - TA - comunicacional conhecida por áudio-descrição (AD) pode minimizar ou eliminar as barreiras físicas e atitudinais e, ao mesmo tempo, proporcionar que a pessoa cega ou com baixa visão possa acessar, interpretar, significar, contextualizar e interagir com tais produções. Tomando-se por base o depoimento de Bazanella (2010), pode-se ter uma ideia da importância e da funcionalidade da $\mathrm{AD}$ como um recurso de TA comunicacional “cujo objetivo é tornar os mais variados tipos de materiais audiovisuais (peças de teatro, filmes, programas de TV, espetáculos de dança, etc.) acessíveis a pessoas não-videntes [...]” (FRANCO; SILVA, 2010, p. 23).

$\mathrm{O}$ ato de narrar fatos, feitos e estórias faz parte de um processo comunicativo secular, contudo, o modo profissional de áudio-descrever produções audiovisuais têm pouco mais 45 anos. Tudo começou, conforme Franco; Silva (2010), com a dissertação de mestrado defendida por Gregory Frazier, em 1975, nos Estados Unidos.

Em nosso país, a Constituição de 1988 é considerada um marco no concernente ao reconhecimento dos direitos das pessoas com deficiência. É imperioso mencionar que o Brasil é um dos signatários do Protocolo Facultativo da Convenção Internacional sobre os Direitos das Pessoas com Deficiência, transformado em Emenda Constitucional por meio no Decreto $\mathrm{n}^{\circ}$ 6.949/2009, em que seu Artigo $9^{\circ}$ refere-se especificamente à acessibilidade e a obrigatoriedade de "assegurar às pessoas com deficiência o acesso, em igualdade de oportunidades com as demais pessoas, [...], à informação e à comunicação, inclusive aos sistemas e tecnologias da informação e comunicação, [...]” (BRASIL, 2009).

Considera-se, de acordo com o Decreto $n^{\circ} 5.296 / 2004$, uma pessoa cega ou com baixa visão aquela cuja 
A cuidade visual é igual ou menor que 0,05 no melhor olho, com a melhor correção óptica; a baixa visão, que significa acuidade visual entre 0,3 e 0,05 no melhor olho, com a melhor correção óptica; os casos nos quais a somatória da medida do campo visual em ambos os olhos for igual ou menor que $60^{\circ}$; ou a ocorrência simultânea de quaisquer das condições anteriores (BRASIL, 2004).

Na busca de desfazer as dúvidas quanto ao modo de se ver o mundo, a Organização Mundial de Saúde estabeleceu a diferença entre a chamada percepção visual e a função visual propriamente dita. Em outras palavras,

A percepção visual é um tipo de função mental caracterizada por reconhecer e interpretar os estímulos visuais. Já a função visual está relacionada à detecção de luz, forma, tamanho, textura e cor por meio do estímulo visual. Dessa maneira, estão incluídas as funções da acuidade visual, do campo visual, da qualidade da visão, da detecção à luz e da cor, a variação da acuidade visual da visão distante e próxima, a visão monocular e a binocular e a qualidade visual da imagem (WHO, 2001 apud MACHADO, 2011, p. 19).

Apresentou-se a percepção sob a ótica orgânica e fisiológica, todavia, nessa investigação, a percepção é focalizada como um fenômeno original, isto é, o

Organismo no universo dos objetos e encerrar este universo através dele, seria preciso traduzir o funcionamento do corpo na linguagem do em si e descobrir, sob o comportamento, a dependência linear entre o estímulo e o receptor, entre o receptor e o Empfinder. Sem dúvida, sabia-se que no circuito do comportamento emergem determinações novas, e a teoria da energia específica dos nervos, por exemplo, concedia ao organismo o poder de transformar o mundo físico. Mas ela justamente atribuía aos aparelhos nervosos a potência oculta de criar as diferentes estruturas de nossa experiência, e, enquanto a visão, o tato, a audição são tantas maneiras de ter acesso ao objeto, essas estruturas achavam-se transformadas em qualidades compactas e derivadas da distinção local entre os órgãos postos em cena. Assim, a relação entre o estímulo e a percepção podia ficar clara e objetiva, o acontecimento psicofísico era do mesmo tipo que as relações da causalidade "mundana" (MERLEAU-PONTY, 1999, p. 111 - 112).

Desta forma, a AD transcende o ato restrito de permitir que uma pessoa cega ou com baixa visão possa acessar um signo imagético por intermédio de um signo verbal e sonoro traduzido, e com a capacidade de se presentificar (HEIDEGGER, 2005) na mente daquela pessoa como um signo imagético semelhante ou equivalente àquele que estava presente na produção audiovisual. Nesta representação, conforme Peirce (2005), “dirigir-se a alguém, isto é, cria na mente dessa pessoa um signo equivalente, ou talvez um signo mais desenvolvido. Ao signo assim criado denomino interpretante do primeiro signo" (PEIRCE, 2005, p. 46). É 
na passagem de uma etapa para outra que ocorre o processo comunicacional em que "o destinatário da mensagem a decodifica amiúde através de um signo interpretante, ocorrendo então um fenômeno conhecido por comutação de código (Code switching)" (BLIKSTEIN, 1997, p. 10).

Seguidor da teoria peirceana, Roman Jakobson foi um intelectual russo que pesquisou o liame entre o som - sound - e o seu significado - meaning. Jakobson (1977) pensou a teoria da tradução amparada em três pilares que sustentam a interpretação de um signo verbal. $\mathrm{O}$ primeiro é a tradução intralingual ou reformulação (rewor-ding); a segunda, a tradução interlingual ou a tradução propriamente dita; e o terceiro e mais importante para essa investigação científica, a "tradução intersemiótica ou transmutação que consiste na interpretação dos signos verbais por meio de sistemas de signos não-verbais" (JAKOBSON, 1977, p. 64).

Considerando-se que a $\mathrm{AD}$ é uma tradução intersemiótica, busca-se no aceno orientador de Plaza (2008) os elementos que subsidiam a compreensão do processo de tradução de signo em signo e, a partir dela, a percepção de um fenômeno mental que se presentifica na pessoa com deficiência visual.

Para esse autor,

Por seu caráter de transmutação de signo em signo qualquer pensamento é necessariamente uma tradução. Quando pensamos, traduzimos aquilo que temos presente à consciência, sejam imagens, sentimentos ou concepções (que, aliás, já são signos ou quase signos) em representações que também servem como signo. Todo o pensamento já a tradução de outro pensamento, pois qualquer pensamento requer ter havido outro pensamento para o qual ele funciona como interpretante (PLAZA, 2008 p. 18).

Pelo exposto, pode-se dizer que a AD é uma tradução intersemiótica dado ao fato que sua característica principal é a intencionalidade em transmitir uma mensagem que foi captada junto a uma produção artístico-cultural pela visão do redator e do áudio-descritor que foi traduzida da linguagem visual para a linguagem escrita e, posteriormente, para a linguagem verbal e sonora. A AD corporifica um signo da linguagem verbal congênere àquele da imagem áudio-descrita e que chega aos ouvidos e, finalmente, à mente da pessoa cega ou com baixa visão com potência para gerar um signo semelhante ou equivalente ao contido na produção audiovisual.

\section{A historicidade e os modelos de áudio-descrição (AD)}


A áudio-descrição conforme Franco; Silva (2012), teve sua origem vinculada à pesquisa realizada por Gregory Frazier para a dissertação de mestrado defendida em 1975, nos Estados Unidos. A áudio-descrição saiu do papel a partir da iniciativa de Cody Pfanstiehl e Margaret Rockwell, esta com deficiência visual e ambos fundadores do serviço de ledores via rádio The Metropolitan Washington Ear. Devido ao sucesso, eles estenderam o trabalho de áudio-descrição aos museus, parques e monumentos norte-americanos. A difusão e os benefícios alcançados foram determinantes para o interesse das emissoras de televisão e a pioneira foi a Public Broadcasting Service (PBS) que, em 1982, convidou Margaret e Cody para áudio-descreverem a série American Playhouse.

Em 1994, “o Metropolitan Washington Ear áudio-descreveu Madame Butterfly para a companhia Washington Opera" e em 1992, “a WGBH deu início ao projeto Motion Picture Access (MoPix) para levar a AD ao cinema em escala comercial" (FRANCO; SILVA, 2012, p. 25).

O primeiro filme áudio-descrito foi "O Chacal". A AD rompeu as fronteiras dos Estados Unidos e aportou na Europa em 1985 no "pequeno teatro Robin Hood em Averham, na Inglaterra" e, em âmbito profissional, no "Theatre Royal em Windsor a partir de 1988, com a peça Stepping Out" (FRANCO; SILVA, 2012, p. 26).

Os espanhóis, em 1987, criaram a Organización Nacional de Ciegos Españoles (ONCE) que promoveu a AD do filme O Último Tango em Paris. Posteriormente, em 1988, foi a vez dos ingleses da Royal National Institute of Blind People (RNIB) áudio-descreveram programas para a televisão e produções audiovisuais daquele país.

Em 1989, o recurso de TA comunicacional foi apresentado na França por ocasião do Festival de Cannes. O filme Indiana Jones e a Última Cruzada recebeu AD de estudantes francesas treinados nos Estados Unidos pela AudioVision Institute. Os alemães que estavam presentes no Festival de Cannes levaram a ideia para seu país e a rede de TV bávara Bayerishes Rundfunk, de Munique, além de disponibilizar programas áudio-descritos também contratou pessoas com deficiência visual para realizarem consultoria da AD das produções.

Ainda tomando-se por base o estudo de Franco; Silva (2012, p. 31), registra-se que a $\mathrm{AD}$ foi ofertada pela primeira vez no Brasil por intermédio dos filmes exibidos pelo "festival temático Assim Vivemos: Festival Internacional de Filmes sobre Deficiência".

Em 2005, ocorreu o lançamento do primeiro filme nacional com AD Irmãos de Fé. Em 2006, foi a vez do Festival Internacional de Curtas-Metragens de São Paulo e em 2007 o Festival de Cinema de Gramado apresentarem filmes com a tecnologia assistiva (TA) comunicacional. No mesmo ano, a AD chegou ao teatro brasileiro com a peça Andaime. Em 
2008, ocorreu a AD do filme Ensaio Sobre a Cegueira; a estreia na televisão brasileira do primeiro comercial áudio-descrito produzido para a empresa de cosméticos Natura e a apresentação de Os Três Audíveis que inaugurou a TA em espetáculos de dança. Outro evento que inovou foi o XIII Festival Amazonas de Ópera com o espetáculo Sansão e Dalila.

Em nosso país, a áudio-descrição de produções audiovisuais, em sua maioria, segue os modelos inglês e espanhol. Apresenta-se, a seguir, algumas diferenças entre estes dois modelos e uma amostragem de alguns elementos que embasam a proposta de um que possa ser chamado de modelo brasileiro de AD.

O modelo espanhol de AD, segundo Bourne; Hurtado (2008), está apoiado nas Normas da Audiodescripción para personas con discapacidad visual que são requisitos legais para a realização de audiodescripción y elaboración de audioguías - AENOR UNE 153020:2005, de 26 de janeiro de 2006. Enquanto o modelo inglês segue as determinações Guidance on Standards for Audiodescription - ITC - 2000. Estes autores elencaram alguns aspectos que devem ser observados para a adequação da $\mathrm{AD}$ à legislação dos dois países: a $\mathrm{AD}$ das cenas envolvendo a identificação das personagens, dos cenários, dos figurinos, entre outros detalhes, deve ser anexada à gravação ou ser falado "ao vivo" no intervalo das falas para não atrapalhar os diálogos. A descrição deve ser informativa e resumida, não emitir juízo de valor. No concernente à comunicação, o modelo espanhol faz uso de orações coordenadas e o inglês utiliza com mais frequência às subordinadas e ambos se valem de muitos adjetivos e verbos. Outra diferença pertinente é que o modelo inglês valoriza e menciona o nome das cores que aparecerem na produção artístico-cultural.

Para a abordagem da proposta de um modelo brasileiro de áudio-descrição, primeiramente, atente-se para as palavras de Alves; Teles; Pereira (2011) que ratificam que a $\mathrm{AD}$ é uma tradução intersemiótica, mas que a transmutação de signo da linguagem visual para a verbal

Não é simples e requer grande perícia do tradutor/audiodescritor, pois não se trata, apenas de descrever o que se vê, mas o que é importante para a compreensão da organização semiótica da obra. Um filme, por exemplo, não é só imagens, é composto também por diálogos, sons, textos que, se não levados em conta pela audiodescrição, esta acabará por prejudicar seu entendimento. Há um consenso de que a audiodescrição não deve se sobrepor aos diálogos do filme. Os indivíduos com deficiência visual deverão ter acesso a conteúdos cinematográficos tal como os videntes, logo, a audiodescrição não deve privá-los de usufruir da informação que eles já recebem naturalmente, a auditiva. Assim, a narração tem que ser adequada aos intervalos de silêncio, devendo, às vezes, ser bastante sintetizada. Não se pode esquecer, também, que a $\mathrm{AD}$, para o deficiente visual, é elemento indispensável para a compreensão da obra, portanto, deve estar ligada a esta de modo a contribuir para a compreensão de seu significado (ALVES; TELES; PEREIRA, 2011, p. 11). 
A partir desse delineamento, docentes, discentes, bolsistas e voluntários da Universidade de Brasília - UnB, deram início ao projeto de $\mathrm{AD}$ que atendesse às demandas dos deficientes visuais brasileiros. Foram selecionados quatro (4) filmes curta-metragem que possuíam um ambiente e personagens adequados à formação do corpus da pesquisa: "A Ilha (2008) e a Rua das Tulipas (2007), ambos de Alê Camargo; Feijão com Arroz (2009), de Daniela Marinho e Dona Custódia (2007) de Adriana Andrade" (ALVES; TELES; PEREIRA, 2011, p. 12).

Para o exercício e a aprendizagem da AD foram criados os roteiros em conformidade com o modelo espanhol e inglês. Na sequência, os roteiros foram gravados e encaminhados para a pesquisa de recepção entre os pacientes do Centro de Educação Especial do Deficiente Visual de Brasília que escolheriam o modelo com a melhor narrativa e possibilidade de interpretação. Para instrumento de análise foram confeccionados três questionários. No primeiro, os participantes deveriam preencher com dados pessoais, como sexo, idade, grau de cegueira e escolaridade. $\mathrm{O}$ segundo, a respeito da $\mathrm{AD}$ dos filmes; e no terceiro questionário, os integrantes da pesquisa manifestariam sua opinião a respeito dos dois modelos e apontando qual deles reunia as melhores condições de ser adotado no país.

Conforme Alves; Teles; Pereira (2011), após a realização de duas reuniões com dois grupos, um com cegueira congênita e outra com a adquirida, o resultado não foi conclusivo. As pesquisadoras identificaram que "outros testes deverão ainda ser realizados [...] e que a performance dos participantes, bem como sua opinião quanto à eficácia, e mesmo quanto à preferência pelo modelo $\mathrm{AD}$, não diferem significativamente de um grupo para outro" (ALVES; TELES; PEREIRA, 2011, p. 22).

Enquanto se aguarda por novos estudos, pesquisas, projetos e definições de um modelo brasileiro de $\mathrm{AD}$, que seja estruturado de acordo com características, necessidades e anseios das pessoas com deficiência visual, os modelos espanhol e inglês continuam a ser utilizados nas produções artístico-culturais do país.

\section{3. Áudio-descrição e fundamentação intersemiótica}

De forma sucinta e explicativa, Mianes (2011, p. 11) identifica a AD como um recurso de TA comunicacional que permite à pessoa cega ou com baixa visão a participação na "vida social e cultural em igualdade de condições” com as demais pessoas e, em razão disso, torna- 
se elemento fulcral "tanto para o incremento de informações quanto para o processo de fruição artística".

Quando observada pela ótica da teoria de Jakobson (2007), pode-se dizer que a AD é uma tradução intersemiótica,

Pois ocorre entre dois meios semióticos diferentes, o visual e o verbal. A tradução visa permitir que, por meio da narração de elementos visuais, o deficiente visual, pessoa cega ou com baixa visão, assista a qualquer produção audiovisual. Essa percepção permite um melhor entendimento do desenrolar de filmes, eventos esportivos, programas televisivos, propagandas, peças de teatro, óperas, museus, etc. Os elementos visuais descritos incluem não apenas o cenário ou uma peça exposta em um museu, mas também o figurino dos atores, as características marcantes dos personagens, os objetos que compõem a cena com significado importante para a trama do filme ou espetáculo, entre outros (SEOANE, 2012, p. 22).

No plano semiótico e intersemiótico tem-se que a $\mathrm{AD}$ se efetiva através de um recurso de TA comunicacional que se utiliza de suportes, de meios e de canais. Acredita-se que a AD passa inevitavelmente pelas 27 modalidades de misturas e combinações referentes às três matrizes propostas por Santaella (2005): a matriz verbal, a matriz visual e a matriz sonora. A autora detalhou como se dá a relação entre as três matrizes e as suas categorias.

\begin{abstract}
A lógica implícita nas categorias também prescreve que, sendo a mais primordial, a categoria da primeridade, está na base, servindo de alicerce à secundidade, assim como esta alicerça a terceridade. Então, a matriz sonora, em nível de primeiro, alicerça a matriz visual, do mesmo modo que alicerça a matriz verbal. Isso também significa dizer que a matriz sonora prescinde da matriz visual - secundidade, do mesmo modo que esta prescinde da matriz verbal - terceridade. Disso ainda decorre que a secundidade, matriz visual, engloba a primeridade, matriz sonora, enquanto a terceridade, matriz verbal, engloba tanto a secundidade, a matriz visual, quanto engloba, naturalmente, a primeridade, a matriz sonora (SANTAELLA, 2005, p. 79).
\end{abstract}

Nessa linha de raciocínio, a AD quando observada sob o prisma semiótico apresenta as características do que Santaella (2009) classifica de binômio linguagem-pensamento que levam à percepção; o que, em última instância, concorda com a teoria peirceana que sacramentou a união indissolúvel entre o pensamento, o signo e a percepção.

Nesta condição, a AD é uma tradução de signos não verbais em verbais e com potencial de causar um fenômeno sígnico que ao se presentificar na mente da pessoa com deficiência tornando-se semelhante ou equivalente àquele que estava presente na produção audiovisual. Desta forma, a AD configura-se como uma mescla de signos visuais, verbais e sonoros. Sublinha-se, portanto, que 
Quando se manifestam em canais específicos, as linguagens adquirem traços que são próprios daquele canal, o que cria a ilusão de uma mera somatória de linguagens e de mídia. Ao contrário, o que aqui postulo é que, por trás dessa proliferação, estão classes finitas e muito vastas de signos-pensamentos. As matrizes da linguagem e pensamento estão sustentadas nas três classes principais de signos: o quali-signo icônico, remático para a sonoridade; sin-signo indicial, dicente para a visualidade e o legi-signo, simbólico, argumental para o discurso verbal. [...] As matrizes também estão relacionadas à percepção e esta aos sentidos humanos. Assim sendo, enquanto a matriz verbal é mais abstrata e, portanto, menos dominada por um sentido determinado, a visual está mais ligada ao olho e ao sentido da visão, enquanto a sonora está ligada ao ouvido e a audição (SANTAELLA, 2009, p. 57).

Pelo exposto, imagina-se a AD suplantando os limites de aspectos meramente técnicos e narrativos de uma produção audiovisual, mas se constitui em um recurso de TA comunicacional que tem em sua essência a potencialidade de proporcionar que uma pessoa cega ou com baixa visão tenha acesso à linguagem imagética por meio da linguagem verbal e sonora, isso, porque

Toda a experiência cognitiva pode ser traduzida e classificada em qualquer língua existente. Onde houver uma deficiência, a terminologia poderá ser modificada por empréstimos, calços, neologismos, transferências semânticas e, finalmente, por circunlóquios (JAKOBSON, 2007, p. 66).

A partir do legado de Jakobson vê-se que a $\mathrm{AD}$ como um recurso de TA que tem a capacidade transitar de signo em signo ou de linguagem em linguagem à medida que passa da imagética para a escrita; para a verbal; para a sonora e, novamente, para linguagem imagética. As linguagens escrita, verbal e sonora devem corresponder à imagética. Quando isso não ocorre o vocabulário adotado pelo redator da $\mathrm{AD}$ deve ser ajustado para um nível que a pessoa com deficiência possa acessar, interpretar, significar e interagir com a produção artístico-cultural.

\section{4. Áudio-descrição: uma tecnologia assistiva comunicacional}

Tecnologia assistiva (TA) conforme o Comitê de Ajudas Técnicas (CAT) é "uma disciplina de domínio de profissionais de várias áreas do conhecimento, que interagem para restaurar a função humana" e que, por conseguinte, fundamenta o investimento em "pesquisa, fabricação, uso de equipamentos, recursos ou estratégias utilizadas para potencializar as habilidades funcionais das pessoas com deficiência" (BRASIL, 2009, p.11). As Tecnologias Assistivas podem ser classificadas em três classes que diferem no enfoque dado a sua 
organização e sua aplicação: O ISO 9999; a Classificação Horizontal European Activities in Rehabilitation Technology (HEART)e a Classificação Nacional de Tecnologia Assistiva, do Instituto Nacional de Pesquisas em Deficiências e Reabilitação, dos Programas da Secretaria de Educação Especial, Departamento de Educação dos Estados Unidos.

No Decreto n 3.298 de 1999, na Seção I, Da Saúde:

Art. 19. Consideram-se ajudas técnicas, para os efeitos deste Decreto, os elementos que permitem compensar uma ou mais limitações funcionais motoras, sensoriais ou mentais da pessoa portadora de deficiência, com o objetivo de permitir-lhe superar as barreiras da comunicação e da mobilidade e de possibilitar sua plena inclusão social (BRASIL, 1999).

E no parágrafo único, esse Decreto estabelece o que são ajudas técnicas:

I - próteses auditivas, visuais e físicas; [...]; VI - elementos especiais para facilitar a comunicação, a informação e a sinalização para pessoa portadora de deficiência; VII - equipamentos e material pedagógico especial para educação, capacitação e recreação da pessoa portadora de deficiência; [...]. (BRASIL, 1999).

Na mesma linha de apresentação do conceito de TA, no Decreto $n^{0}$ 5.296/2004 podese encontrar no Capítulo VII, Das Ajudas Técnicas:

Art. 61. Consideram-se ajudas técnicas os produtos, instrumentos, equipamentos ou tecnologias adaptados ou especialmente projetados para melhorar a funcionalidade da pessoa portadora de deficiência ou com mobilidade reduzida, favorecendo a autonomia pessoal, total ou assistida. (BRASIL, 2004)

O trabalho desenvolvido pelo CAT sustenta-se em uma rede conceitual e utiliza-se de termos referenciais que são usados em diversos países de língua inglesa e nesses locais tais recursos são conhecidos como Assistive Technology, nos programas de língua espanhola como Ayudas Técnicas e nos programas de língua portuguesa como Tecnologia de Apoio. No Brasil, "Tecnologia Assistiva é uma expressão nova, que se refere a um conceito ainda em pleno processo de construção e sistematização" (GARCÍA; FILHO, 2012, p. 12). Para estes pesquisadores, a utilização de um pedaço de madeira usada como bengala, por exemplo, pode ser considerada como um recurso de tecnologia assistiva.

Reforça-se que para a existência de uma sociedade verdadeiramente inclusiva deve-se planejar, investir, desenvolver e oferecer recursos de TA comunicacional que observem os preceitos do Desenho Universal. De acordo com Carletto e Cambiaghi (2008), o conceito de Desenho Universal é oriundo da área de arquitetura da Universidade da Carolina do Norte, 
Estados Unidos e se refere a projetos, produtos, ambientes e serviços acessíveis, a todas as pessoas, com segurança e autonomia. O termo Universal Design foi criado em 1987, por Ron Mace, pessoa com deficiência que fazia uso de cadeira de rodas e respirador artificial, e, que em 1990, junto a outros arquitetos apresentou os sete (7) princípios do Desenho Universal. E esses são basilares para a promoção de acessibilidade em nível mundial. Sendo eles:

1. IGUALITÁRIO: [...] São espaços, objetos e produtos que podem ser utilizados por pessoas de diferentes capacidades, tornando os ambientes iguais para todos. 2 . ADAPTÁVEL: [...] Design de produtos ou espaços que atendem com diferentes habilidades e diversas preferências, sendo adaptáveis a qualquer uso. 3. ÓBVIO: [...] De fácil entendimento, para que a pessoa possa compreender, independentemente de sua experiência, conhecimento, habilidades de linguagem ou nível de concentração. 4. CONHECIMENTO: [...] Quando a informação necessária é transmitida de forma a atender as necessidades do receptor, seja ela uma pessoa estrangeira, com dificuldade de visão ou audição. 5. SEGURO [...] Previsto para minimizar os riscos e possíveis consequências de ações acidentais ou não intencionais. 6. SEM ESFORÇO [...] Economia de energia. Fácil manipulação. 7. ABRANGENTE [...] Dimensão e espaço para a aproximação de uso. Dimensão = sentido em que se mede a extensão para avaliar. Medida, tamanho (CARLETTO; CAMBIAGHI, 2008, p. 12 $-17)$.

Considera-se que a criação, a organização, o uso de técnicas e de tecnologias semelhantes às internacionais propiciaram ao Comitê de Ajudas Técnicas brasileiro as condições mínimas e necessárias para a pesquisa, o desenvolvimento, a fiscalização e a difusão de produtos, recursos e serviços de acessibilidade comunicacional que são indispensáveis para a inclusão cultural das pessoas com deficiência.

\section{5. Áudio-descrição, pessoa com deficiência e a Legislação Brasileira}

Ao se verificar as primeiras Constituições do Brasil, a de 1824 e a de 1891, respectivamente, observa-se que não existe menção ao direito das pessoas com deficiência. $\mathrm{O}$ Documento de 1934, em seu artigo 138, define: “Incumbe à União, aos Estados e aos Municípios, nos termos das leis respectivas: a) Assegurar amparo aos desvalidos, criando serviços especializados e animando os serviços sociais, [...]” (BRASIL, 1934). A Carta Magna de 1937 excluiu o Artigo supracitado. Na de 1946, Artigo 157, Inciso XVI - retomou o desejo do legislador em garantir que o Estado brasileiro custeasse por meio da "previdência, mediante contribuição da União, do empregador e do empregado, em favor da [...] invalidez [...]" (BRASIL, 1946). A Emenda Constitucional nº 1, de 17 de outubro de 1969, no Artigo 175 , “§ $4^{\circ}$ Lei especial disporá [... ] sôbre a educação de excepcionais” (BRASIL, 1969). A 
Emenda Constitucional $n^{\circ}$ 12, de 17 de outubro de 1978 em seu Artigo único, assegura às pessoas com deficiência a educação especial e gratuita, bem como a assistência, a reabilitação e reinserção, na vida econômica e social do país; a proibição de discriminação, inclusive quanto à admissão ao trabalho ou ao serviço público e a salário e a possibilidade de acesso a edifícios e logradouros públicos.

A Constituição Cidadã, de 1988, além de reconhecer e ratificar os direitos das pessoas com deficiência, como expresso no Artigo $5^{\circ}$ declara que

Todos são iguais perante a lei, sem distinção de qualquer natureza, garantindo-se aos brasileiros e aos estrangeiros residentes no País a inviolabilidade do direito à vida, à liberdade, à igualdade, à segurança e à propriedade [...] (BRASIL, 1988).

Outra legislação relevante para a proteção dos direitos das pessoas com deficiência é o Decreto $n^{\circ} 6.949$, de 25 de agosto de 2009, que promulgou a Convenção Internacional sobre os Direitos das Pessoas com Deficiência e seu Protocolo Facultativo, assinados em Nova York, em 30 de março de 2007. Na mesma direção encontram-se as Leis $n^{\circ} 10.098$ de 19 de dezembro de 2000 que estabelece normas gerais e critérios básicos para a promoção da acessibilidade das pessoas portadoras de deficiência ou com mobilidade reduzida; o Decreto $\mathrm{n}^{\mathrm{o}} 5.296$ de 2 de dezembro de 2004, que regulamenta as Leis $\mathrm{n}^{\mathrm{o}} 10.048$, de 8 de novembro de 2000, que dá prioridade de atendimento às pessoas que especifica e a Norma Complementar $n^{\circ}$ 01/2006 que trata dos Recursos de acessibilidade, para pessoas com deficiência, na programação veiculada nos serviços de radiodifusão de sons e imagens e de retransmissão de televisão. Essa Norma classifica áudio-descrição como um recurso de tecnologia assistiva de acessibilidade comunicacional que "corresponde a uma locução, em língua portuguesa, sobreposta ao som original do programa, destinada a descrever imagens, sons, textos e demais informações que não poderiam ser percebidos ou compreendidos por pessoas com deficiência visual" (BRASIL, 2006).

Acredita-se que o Decreto $n^{\circ}$ 6.949, de 25 de agosto de 2009, constitui-se como um "divisor" de águas na consecução dos direitos das pessoas com deficiência, pois reconhece que a deficiência é um conceito em evolução e resultante da interação com as barreiras físicas e atitudinais que as impede de participar plena e efetivamente da vida cultural em condições e oportunidade equânimes às dos demais brasileiros. 


\section{Conclusões}

Pelo descrito, verificou-se que o arcabouço legal brasileiro foi marcado por evoluções e involuções, no entanto, numa sociedade justa e equânime o respeito pelas pessoas não deveria frutificar tão somente por estar normalizado e sim, como uma forma de acolhimento e empatia. Por esse viés, todos seriam reconhecidos e valorizados como sujeitos de direito, integrais e não observados a partir de suas diferenças físicas, orgânicas, estruturais e intelectuais, etc.

A AD como recurso utilizado com intuito de promover a inclusão cultural das pessoas com deficiência visual cumpre a sua função de "derrubar" barreiras físicas e atitudinais que selecionam, segregam, causam sofrimento, frustação e, por fim, o afastamento destas pessoas do convívio social e cultural.

E infere-se que a AD é uma tradução intersemiótica, conforme a teoria de Roman Jakobson, pois o recurso de tecnologia assistiva comunicacional pode ser usado para a tradução de signo imagético; em signo visual escrito; em signo verbal e sonoro e, ao atingir o ouvido e a mente da pessoa com deficiência, ser traduzido em signo imagético.

\section{Referências}

\section{AENOR UNE 153020:2005. Audiodescripción para personas con discapacidad visual.} Requisitos para la audiodescripción y elaboración de audioguías. Disponível em: $<$ http://www.en.aenor.es/aenor/normas/buscadornormas/resultadobuscnormas.asp?tipo1=\&op cion $=1 \&$ boton $=$ Ver\&pag=\&opproyecto=vigor\&opproyecto $2=$ vigor\&opproyecto3=\&logico $=\mathrm{n}$ o\&tipo $2=\&$ forma $=1 \&$ texto $=\&$ numuno $=\&$ clave $=\& c t n=\&$ numdos $=\&$ numtres $=\&$ estadonorma $=$ Vigente\&ics $=11.180 .99>$. Acesso em 21. Jun. 2017

ALVES, S. F.; TELES, V. C.; PEREIRA, T. V. Propostas para um modelo brasileiro de audiodescrição para deficientes visuais. In. Tradução \& Comunicação - Revista Brasileira de Tradutores. $\mathrm{n}^{\circ}$ 22, Ano 2011. Disponível em: < http://www.pgsskroton.com.br/seer/index.php/traducom/article/viewFile/1853/1761>. Acesso em: 11. Jun. 2017. 
BOURNE, J.; JIMÉNEZ HURTADO, C. From the visual to the verbal in two languages: a contrastive analysis of the audio description of The Hours in English and Spanish. In: DÍAZ-CINTAS, Jorge. (ed.) The didactics of audiovisual translation. Amsterdam / Philadelphia: John Benjamins Publishing Company, 2008.

BRASIL. Constituição dos Estados Unidos do Brasil, de 10 de novembro de 1937. Disponível em: <http://www.planalto.gov.br/ccivil_03/constituicao/constituicao37.htm>. Acesso 03. Abr. 2017.

\section{Constituição dos Estados Unidos do Brasil, de 18 de setembro de 1946.}

Disponível em: < http://www.planalto.gov.br/ccivil_03/Constituicao/Constituicao46.htm>. Acesso em 02. Abr. 2017.

Constituição Política do Império do Brazil, de 25 de março de 1824. Disponível em: <http://www.planalto.gov.br/ccivil_03/Constituicao/Constituicao24.htm>. Acesso em 13. Abr. 2017

Constituição da República dos Estados Unidos do Brasil, de 16 de julho de 1934. Disponível em: <http://www.planalto.gov.br/ccivil_03/constituicao/constituicao34.htm>. Acesso em 05. Abr. 2017.

\section{Constituição da República Federativa do Brasil de 1988.}

Disponível em: http://www.planalto.gov.br/ccivil_03/constituicao/constituicao.htm>. Acesso em 25. Mar. 2017

Decreto $\mathbf{n}^{\mathbf{0}}$ 5.296, de 2 de dezembro de 2004. Regulamenta as Leis nos 10.048, de 8 de novembro de 2000, que dá prioridade de atendimento às pessoas que especifica, e 10.098, de 19 de dezembro de 2000, que estabelece normas gerais e critérios básicos para a promoção da acessibilidade das pessoas portadoras de deficiência ou com mobilidade reduzida, e dá outras providências. Disponível em: <http://www.planalto.gov.br/ccivil_03/_ato20042006/2004/decreto/d5296.htm>. Acesso em: 19. Abr. 2017.

Decreto $n^{0}$ 6.949, de 25 de agosto de 2009. Promulga a Convenção Internacional sobre os Direitos das Pessoas com Deficiência e seu Protocolo Facultativo, assinados em Nova York, em 30 de março de 2007. Disponível em: <http://www.planalto.gov.br/ccivil_03/_ato2007-2010/2009/decreto/d6949.htm>. Acesso em 18. Abr. 2017.

Emenda Constitucional $\mathbf{n}^{\circ} 1$, de 17 de outubro de 1969. Edita o novo texto da Constituição Federal de 24 de janeiro de 1967. Disponível em: $<$ http://www.planalto.gov.br/ccivil_03/Constituicao/Emendas/Emc_anterior1988/emc0169.htm>. Acesso: 05. Abr. 2017.

Emenda Constitucional $\mathrm{n}^{\circ}$ 12, de 17 de outubro de 1978. Assegura aos Deficientes a melhoria de sua condição social e econômica. Disponível em: 
<http://www.planalto.gov.br/ccivil_03/constituicao/emendas/emc_anterior1988/emc1278.htm>. Acesso em: 23. Mar. 2017.

Lei no 10.098 de 19 de dezembro de 2000. Estabelece normas gerais e critérios básicos para a promoção da acessibilidade das pessoas portadoras de deficiência ou com mobilidade reduzida, e dá outras providências.

Disponível em: <http://www.planalto.gov.br/ccivil_03/leis/L10098.htm>.

Acesso em 18. Abr. 2017.

Norma Complementar $\mathbf{n}^{\mathbf{0}} \mathbf{0 1 / 2 0 0 6}$. Recursos de acessibilidade, para pessoas com deficiência, na programação veiculada nos serviços de radiodifusão de sons e imagens e de retransmissão de televisão.

Disponível em: < http://www.mc.gov.br/normas/26752-norma-complementar-n-01-2006>. Acesso em 18. Abr. 2017.

Decreto $\mathbf{n}^{0}$ 3.298, de 20 de dezembro de 1999. Regulamenta a Lei no 7.853, de 24 de outubro de 1989, dispõe sobre a Política Nacional para a Integração da Pessoa Portadora de Deficiência, consolida as normas de proteção, e dá outras providências. Disponível em: < http://www.planalto.gov.br/ccivil_03/decreto/d3298.htm>. Acesso em 10 Abr. 2017.

BAZANELLA, L. A. Um caminho sem volta. In. Audiodescrição : transformando imagens em palavras. São Paulo: Secretaria dos Direitos da Pessoa com Deficiência do Estado de São Paulo, 2010.

BLIKSTEIN, I. Prefácio. In. Linguística e Comunicação. 24. ed. Trad. Blikstein I. e Paes J. P. São Paulo: Cultrix, 2007.

FRANCO, E. P. C.; SILVA, M. C. C. C. Áudiodescrição: transformando imagens em palavras. São Paulo: Secretaria dos Direitos da Pessoa com Deficiência do Estado de São Paulo, 2010.

Audiodescrição: Breve passeio histórico. In. Áudiodescrição: transformando imagens em palavras. São Paulo: Secretaria dos Direitos da Pessoa com Deficiência do Estado de São Paulo, 2010.

GARCIA, J.C.D.; FILHO, T. A.G. Pesquisa Nacional de Tecnologia Assistiva. São Paulo: ITS Brasil/MCTI-SECIS, 2012.

HEIDEGGER, M. Ser e tempo. Trad. Márcia Sá Cavalcanti Schuback. 15. ed. São Paulo: Vozes, 2005.

JAKOBSON, R. Linguística e Comunicação. 24. ed. Trad. BLIKSTEIN. I.; PAES, J. P. São Paulo: Cultrix, 2007.

JÚNIOR, J. N. de O.; FILHO, P. H. L. P. A (não)neutralidade em roteiros de audiodescrição-AD de filmes de curta-metragem via sistema de avaliatividade. In. 
Audiodescrição: práticas e reflexões. Org. Daiana Stockey Carpes - Santa Cruz do Sul:

Catarse, 2016. Disponível em <http://www.audiodescrição-práticas-e-reflexões.pdf>. Acesso em 01. Jul.2017.

MERLEAU-PONTY, M. Fenomenologia da percepção. Trad. Carlos Alberto Ribeiro de Moura. São Paulo: Martins Fontes, 1999.

MIANNES, F. L. Consultoria em audiodescrição: alguns caminhos e possibilidades. Audiodescrição: práticas e reflexões. Org. CARPES, D. S. - Santa Cruz do Sul: Catarse, 2016. Disponível em: http://www.ufpb.br/cia/contents/manuais/livro-audiodescricao-praticase-reflexoes.pdf>. Acesso em 01. Jun. 2017.

MOTTA, L. M. V. de M. M.; ROMEU FILHO, P. (Org.). Audiodescrição: transformando imagens em palavras. São Paulo: Secretaria de Estado dos Direitos da Pessoa com Deficiência, 2010.

OLIVEIRA, L. M. B. Cartilha do Censo 2010 - Pessoas com Deficiência Secretaria de Direitos Humanos da Presidência da República (SDH/PR). Brasília : SDH-PR/SNPD, 2012. Disponível em: $<$ http://www.pessoacomdeficiencia.gov.br/app/sites/default/files/publicacoes/cartilhacenso-2010-pessoas-com-deficienciareduzido.pdf >. Acesso em 18. Jun. 2017.

PLAZA, J. Tradução intersemiótica. $1^{\text {a }}$ ed. - São Paulo: Perspectiva, 2008.

PIERCE, C. S. Semiótica. Trad. José Teixeira Coelho Neto. São Paulo: Perspectiva, 2005.

SANTAELLA, L. Matrizes da linguagem e pensamento: sonora visual verbal: aplicações na hipermídia. 3 ed. - São Paulo: Iluminuras, 2009.

O que é semiótica. São Paulo: Brasiliense, 2007.

SEEMANN, P. A. A.; LIMA, F. J. de; LIMA, R. F. Áudio-descrição no Acordo Ortográfico da Língua Portuguesa: Um estudo morfológico. In: Revista Brasileira de Tradução Visual (RBTV). Vol. 13, 2012. Disponível em: 〈http://www.rbtv. associadosdainclusao.com.br>. Acesso 19 Abr. 2017.

SEOANE, A. F. A priorização de informação em roteiros de audiodescrição: O que o rastreamento ocular nos tem a dizer? - Dissertação (Mestrado) - Universidade Estadual do Ceará, Centro de Humanidades, Curso de Mestrado Acadêmico em Linguística Aplicada, Fortaleza, 2012. Disponível em:

<http://www.uece.br/posla/dmdocuments/AlexandraFrazaoSeoane.pdf >. Acesso 03. Jun. 2017. 
RELACult - Revista Latino-Americana de Estudos em Cultura e Sociedade

Revista Latinoamericana de Estudios en Cultura y Sociedad | Latin American Journal of Studies in Culture and Society V. 03, ed. especial, dez., 2017, artigo $\mathrm{n}^{\circ}$ 526 | relacult.claec.org |e-ISSN: 2525-7870

WILDER, G. S. Inclusão social e cultural: arte contemporânea e educação em museus.

São Paulo: UNESP, 2009. 